\title{
Ore dilution control practised at Sindesar Khurd Mine of Hindustan Zinc Ltd
}

S Dutta Hindustan Zinc Ltd, India

A Lal Hindustan Zinc Ltd, India

V Chittora Hindustan Zinc Ltd, India

L Chordia Hindustan Zinc Ltd, India

D Tailor Hindustan Zinc Ltd, India

\begin{abstract}
Ore dilution has been a major operating challenge in the underground open stoping operations at Sindesar Khurd Mine of Hindustan Zinc Ltd, India. The impact of ore dilution, affecting both the direct and indirect cost of production, has been detrimental to the economics of the mine showing chances of exponential effect in hampering profitability. The authors provide an overview of the various issues influencing dilution in the underground operations. This paper highlights the stages of stringent orebody delineation, grade modelling/contouring, proper stope development, scientific stope design and sequencing, controlled drilling and blasting, and improving mine management. It reviews the entire system improvement that has steadily resulted in effective reduction in planned dilution (17.23-5.72\%) and external dilution (8.83-3.28\%) from 2011-2012 through to 2014-2015.
\end{abstract}

\section{Introduction}

The importance of effective dilution control has been well understood at Sindesar Khurd Mine (SKM). The mine is situated in Rajasthan, India, and operated by Hindustan Zinc Ltd, under Vedanta Group (Figure 1). This base metal mine is high in reserves of lead, zinc and silver (reserves and resources $>90 \mathrm{Mt}$ in 2013) with production of $2 \mathrm{Mt} /$ annum ore in 2014-2015 and ambitious plans to reach 3 and $3.75 \mathrm{Mt} /$ year in 2015-2016 and 2017-2018 respectively. SKM has gained prominence as a major underground base metal mine with the introduction of the latest mining techniques and achievement of high production with quality and safety at lowest costs (the mine is presently the largest underground metal mine in India). The SKM orebody exhibits significant variations and complexity in geometry and metal distribution. The mining method used is longhole open stoping (LHOS), which is a comparatively economic method but requires effective stope delineation, as selective mining is difficult. Dilution realised for a particular open stope is a measure of quality of design and mining practice. Excessive dilution causes economic losses, as waste has to be handled, transported and treated in the mill. The objective of reducing dilution is to maximise revenue through efficient designs, good mining practices, efficient monitoring and effective control. Absence of a proper dilution control system at SKM had previously caused large variations between monthly forecasts and mill results, affecting both mill recovery and budget costs. High dilution in mine production at SKM has been due to a lack of proper orebody delineation and grade contouring, leading to high design dilution (planned dilution), and incomplete geotechnical understanding and drilling and blasting issues that caused excessive unplanned dilution. The major factors that contributed to high planned dilution and high unplanned dilution included:

- Insufficient exploration and gaps in orebody delineation.

- Inadequate information on internal low grade/waste inclusions.

- Improper stope design, sequencing and stope development. 
- Need for drilling accuracy and control of blast vibration.

- Ground support and stope wall stability.

- Production and mine management issues.

The identification and analysis of the different sources of dilution have been completed for each individual stope by cross-discipline groups, including the geology cell, mine planning cell, rock mechanics cell and operations teams. Remedial measures have been taken, with continual feedback on the actual dilution, by utilising cavity monitoring survey (CMS) of all stope voids, to reveal deviations between planned stoping boundary and actual excavated stope boundary.

The action plan included definition and identification of the dilution sources, strategy for measurement and implementation of corrective actions, and setting realistic targets for dilution reduction for both short- and long-term plans. The success was based on regular interaction with all mining personnel regarding planned targets and the economic importance.

\section{Geology}

SKM occupies part of the eastern limb of the Dariba-bethumani doubly plunging synform. The structural imprints show at least four stages of deformation and the doubly plunging synform access trends NE-SW, with a steep dip towards west. The calc-silicate bearing dolomite lens present in the mica-schist-chert horizon forms the principle host rock for the sphalerite-galena mineralisation. The carboniferous schist forms the sub-ordinate host in terms of grade. The mine extends $1,300 \mathrm{~m}$ along strike from $120-920 \mathrm{~m}$ below surface and ranges from $5-60 \mathrm{~m}$ in thickness. The overall dip, which varies from $37-70^{\circ}$, is to the east but becomes overturned below the $120 \mathrm{mRL}$ elevation. The total reserves and resources as of 1 April 2013 are $90 \mathrm{Mt}$ at $4.50 \% \mathrm{Zn}, 2.50 \% \mathrm{~Pb}$ and $156 \mathrm{ppm} \mathrm{Ag}$ (up to $1,100 \mathrm{~m}$ depth (-615 mRL)). The reserves and resources were computed through high technology, high-speed exploration drilling, and by using inverse distance square (IDS) for block modelling with Datamine ${ }^{\circledR}$ Studio-3 software. The life-of-mine is estimated at $>35$ years from 2013-14 at $2 \mathrm{Mt}$ production per year.

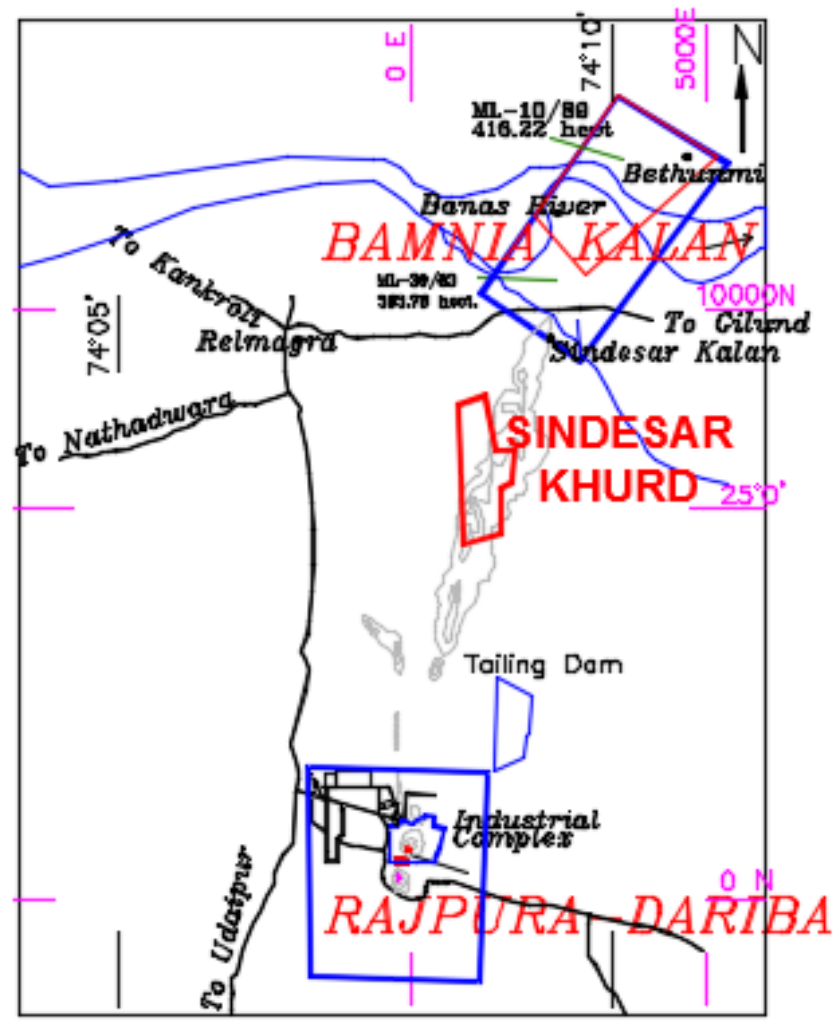

Figure 1 Mine location map 


\section{$3 \quad$ Mineralisation and exploration needs}

The geometry and spatial grade distribution of the orebody at SKM is typically highly disturbed both along strike and down dip, leading to highly erratic mineralisation geometry and resulting in an orebody with variable and irregular zones of low grade and high grade ore. Efficient, effective and accurate delineation of such a deposit has been necessary through increased geotechnical and exploration information-density to maximise recovery and minimise dilution while increasing safety.

The delineation of stoping boundaries and the economic recovery of the resource/reserve at SKM have been very difficult due to complexity in orebody geometry. Internal dilution is caused by the inclusion of low grade material contained within stoping boundaries. Its inclusion may be known (planned dilution) or unknown (geological dilution) due to insufficient internal delineation of waste pockets. Minimisation of planned dilution requires diligent statistical analysis of assay values in each stope in order to include or exclude the waste of lower grade patches, which would enable a practical stoping geometry leading to higher recovery with minimal dilution. Unlike uniform tabular deposits, the SKM orebody is randomly fractured in thin lenses of different shapes having frequent variations in grade distribution (Figure 13) in the host rock. This has made ore delineation and stope boundary projections both in the hang wall (HW) and footwall (FW) contacts, and stope grade predictions, very difficult. It has caused large variations in metal concentrate (MIC) predictions.

After analysis, it has been observed that initial exploration predictions were based on $100 \mathrm{~m}$ interval surface drill holes, which were mostly sub-parallel to dip and strike thus giving apparent values. The detailed exploration from underground definition drilling, done at closer interval of $25 \mathrm{~m}$ and subsequently at $12.5 \mathrm{~m}$, show that actual orebody geometry and grade distribution differs widely from that projected from the initial surface boreholes. Further experience has indicated that increasing the exploration drill-density is likely to decrease internal dilution and ore losses. Hence, close interval underground exploratory holes (interval reduced from 50-12.5 m) and high rate of drilling (increased from 12-70 m/day) to meet high mine development targets have been essential to control mine dilution, including geological dilution and planned dilution. The high rate exploration drilling also required a matching high rate sampling and assay system (120 to about 140 samples per day) in the mine to provide a realistic orebody model and thus enable timely and proper mine development planning and optimum stope boundary preparation.

\section{$4 \quad$ Mobile core drilling machine}

The gaps in exploration data obtained from surface exploration have been reduced as discussed above by introducing a new versatile and mobile core drilling machine for underground exploration. The machine is Atlas Copco make with brand name as Diamec MCR-U6. This boom type electro-hydraulic core drill has the capacity for drilling A to $\mathrm{N}$ size core, depth 1,300 m, at torque $940 \mathrm{Nm}, 1,600 \mathrm{rpm}$, with pull-push at $65 \mathrm{KN}$. The high-mobility Diamec MCR-U6 underground core drilling rig is a completely self-sufficient, fully equipped rig. Its one-piece design makes it quick and easy to set up and move around. The control panel is placed on the carrier under the roof to ensure safe drilling operations.

This provides a capability of between $800-1,200 \mathrm{~m} /$ month and has enhanced orebody delineation and grade modelling, and kept pace with stope development needs and high production targets. Timely ore delineation and detailed grade prediction have been possible with the introduction of this machine. 


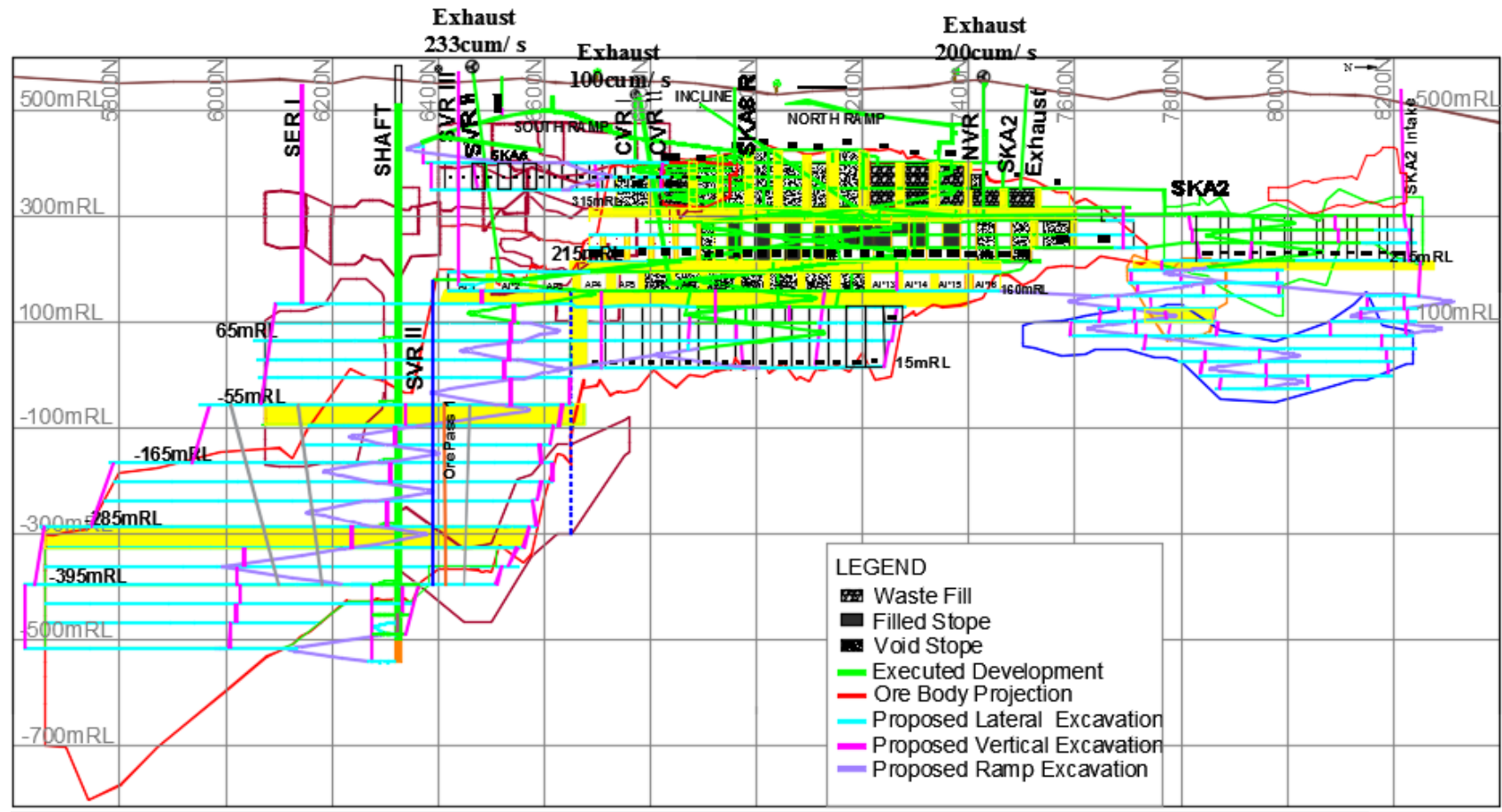

Figure 2 Longitudinal section of the mine

\section{$5 \quad$ Mining}

The underground is currently accessed and supported from five openings comprising of two ramps, two ventilation raises and an old incline, as shown in longitudinal section (LS) (Figure 2). The north ramp, recently widened from $4.5 \times 3 \mathrm{~m}$ at 1 in 8 to $5.5 \times 5 \mathrm{~m}$, and the south ramp, $5.5 \times 5 \mathrm{~m}, 1$ in 8 gradient (Figure 3), are suitable for $50 \mathrm{t}$ low profile dump trucks (LPDT) and $17 \mathrm{t}$ load haul dump (LHD) units. The old incline $(3.5 \times 2 \mathrm{~m})$ is dismantled and serves as a secondary escape and air intake. The north and central ventilation raises are equipped with suitable exhaust fans. To improve ventilation, two more $3.5 \mathrm{~m}$ diameter raises were recently bored for additional air intake and to support the ventilation requirements of an increased equipment fleet.

The compressor house, waste and ore stockpiles, diesel filling station, office building, beneficiation plant, paste fill plant, hydraulic fill plant and proposed plantation area (required statutorily) are located in the mine lease area.

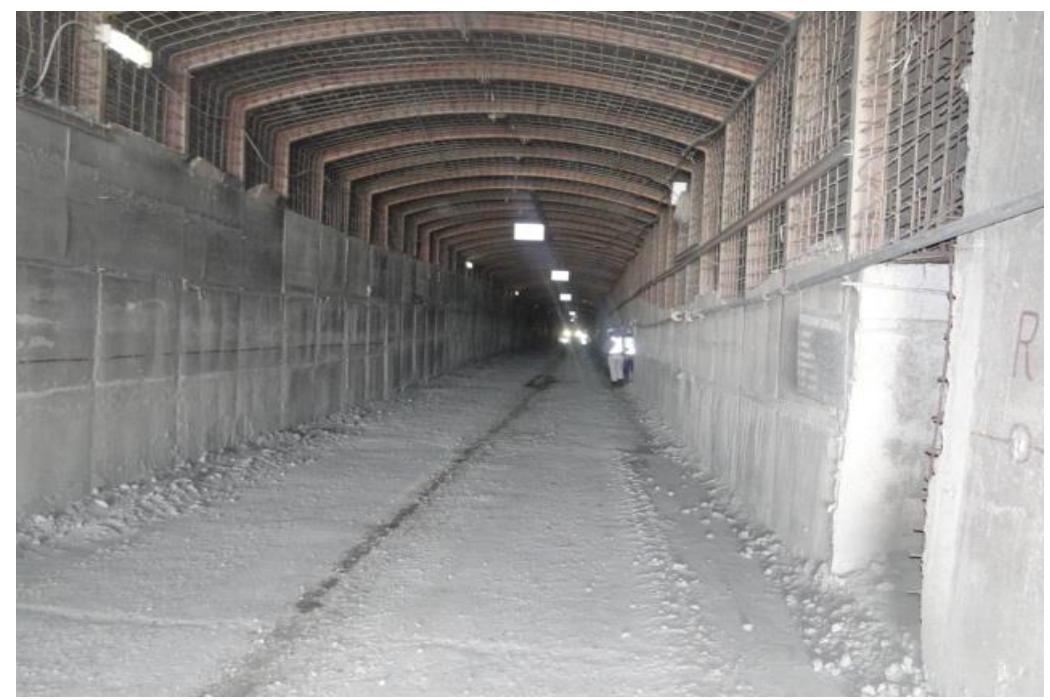

Figure 3 South ramp $(5.5 \times 5.0 \mathrm{~m})$ 
Current mine operations occur in two stoping areas:

- Between 315 and $425 \mathrm{mRL}$ by open stoping method (surface $545 \mathrm{mRL}$ ), utilising a blasthole stoping method, leaving intact rib pillars at intervals of $40-50 \mathrm{~m}$.

- Between 215-290 mRL by primary/secondary sequencing with post filling in stope lengths of $30 \mathrm{~m}$.

- A crown pillar is left between the two stoping blocks between 290 and $315 \mathrm{mRL}$, isolating the two stoping areas.

Backfilling in the lower block is done by hydraulic or paste fill with tailings from the site beneficiation plant. For each blasthole stope, a transverse slot is opened at the widest orebody section by slashing against a slot raise opened by drop raising at one end of slot using $115 / 89 \mathrm{~mm}$ diameter holes. The production rings from oredrives are then blasted against the slot retreating along strike. For large sublevel height (40-50 m), the slot is drilled by $115-165 \mathrm{~mm}$ holes and opened by the vertical crater retreat or drop raise technique. Teleremote operating LHDs are used to recover broken muck in wide orebodies.

Below $215 \mathrm{mRL}$, crown pillars are located between 215 and $190 \mathrm{mRL}$ and between 160 and $130 \mathrm{mRL}$, defining the stoping blocks between 160-190 mRL (30 m height) and 130-15 mRL (115 m height), depending upon orebody width variations, so as to minimise ore blocked in pillars. Figure 2 shows the mine longitudinal-vertical-projection (LVS), depicting the various stoping blocks and stope geometry. Design of crown pillar (location and its thickness), stope geometry and sequence of stope excavation have been done after detailed scientific studies using numerical modelling analysis. For numerical modelling, FLAC2D and 3D software (ITASCA Minneapolis, USA) have been used. All data inputs like in situ stress regime, physico-mechanical properties of rock types, rock mass rating (RMR) etc. have been determined from hydro-fracture tests, laboratory tests on core samples and geotechnical mapping, respectively. Continual feedback from extensive ground instrumentation (borehole extensometer and uniaxial stress metre data) are used to calibrate and update the numerical model.

With continual site monitoring and modelling predictions, the stoping parameters have been steadily optimised from the upper levels to the lower levels. In the upper levels (400-300 mRL), large open stopes having $50 \mathrm{~m}$ sublevel height and 40-45 m strike length were designed and blastholes of $165 \mathrm{~mm}$ diameter were used (in-the-hole (ITH) machines used for drilling). With experience gained in the upper levels, the lower level stope geometry has been optimised. The stopes have been reduced to $35 \mathrm{~m}$ sublevel interval, $30 \mathrm{~m}$ strike length, and blastholes reduced to 115 and $89 \mathrm{~mm}$ diameter (electro-hydraulic drill machines used for drilling). With the optimisation of stope geometry and blasthole diameter, the drilling quality is improved and blast vibration damage has been reduced, which improved stope wall stability.

The need to maximise ore recovery has led the mine to introduce a primary-secondary stoping sequence with post filling using classified mill tails hydraulic backfill. This process is being replaced by the recently commissioned paste fill system to enhance stope sequencing and to ensure local and regional ground stability and minimise fill and wall dilution.

\section{$6 \quad$ Mine development and waste/ore handling}

The mine is based on a trackless system of transportation with two surface ramps connecting all levels. To mine deeper levels below $500 \mathrm{~m}$, a $7.5 \mathrm{~m}$ diameter shaft is being sunk to $1,000 \mathrm{~m}$ depth and will be fitted with a double skip and a cage winding system. All development drifts are greater than $4.5 \times 4 \mathrm{~m}$ in profile and, where large LPDTs $(50 \mathrm{t})$ are required to enter, the size is increased to $5.5 \times 5 \mathrm{~m}$ in profile. Development headings are driven using single/double boom jumbos and mucked with a 10-30 t LPDT combination. Wherever possible, the waste muck is dumped in open stope voids, reducing tramming time. Stope development oredrives are strictly monitored/controlled by geologists and mine surveyors to minimise unnecessary waste development and, as a rule, no extra developments are allowed in HW waste rocks, both at extraction and drill levels, so that undercutting and weakening of wall rocks are prevented. Blasthole rings impinging against the weak HW contact are avoided by rational location of the drill sill oredrive. The oredrives at drill sill level are designed parallel and close to the HW contact enabling design of 
blastholes semi-parallel to HW contact. For this, orebodies need to be properly defined at these levels through definition drilling from underground.

For ore handling, diesel operated LHDs of 10 and $17 \mathrm{t}$ capacities are used at stope extraction levels to muck ore from stope brow to the ore transfer passes. At the bottom of the transfer pass, ore is drawn by $17 \mathrm{t}$ LHDs and loaded into the $50 \mathrm{t}$ LPDTs (Figure 4), which haul the ore through ramps to surface. Wherever practical, stope voids are identified to handle mine development waste, and excess development waste is hauled to the surface waste dump.
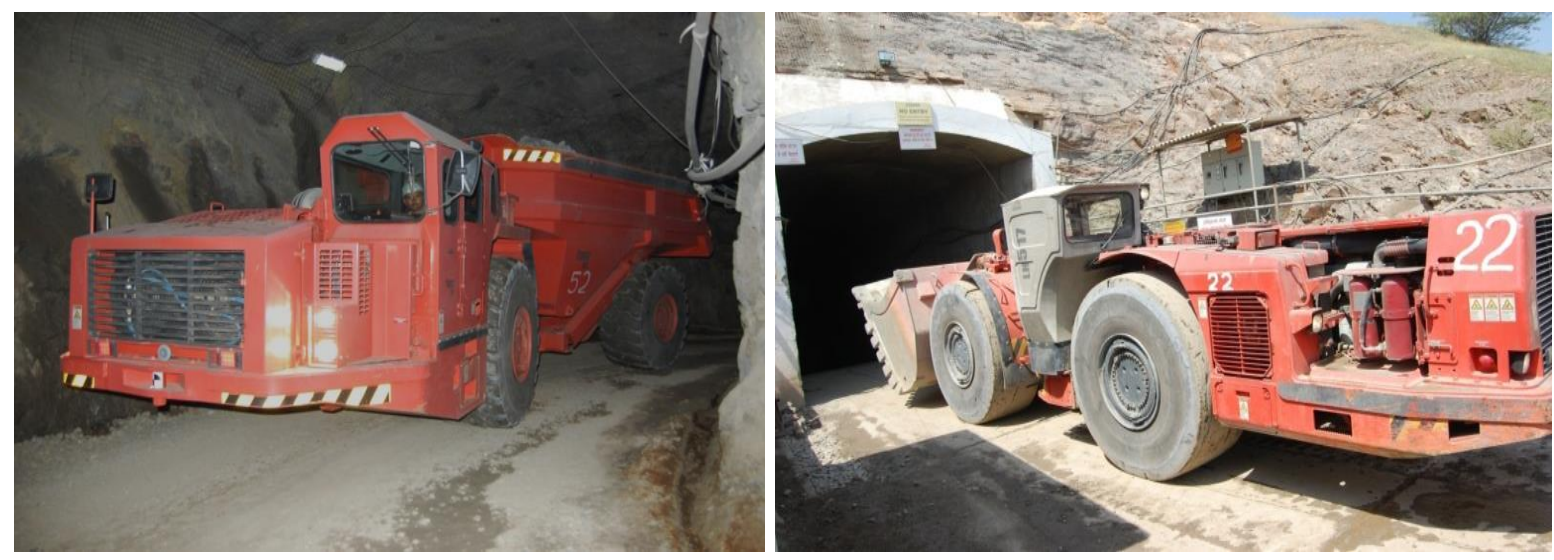

Figure 4 LPDT-50 $\mathrm{t}$ and DLHD-17 $\mathrm{t}$

\section{$7 \quad$ Mine planning and design}

The planning team continually update orebody models in Datamine ${ }^{\circledR}$ software, design stoping boundaries for each stope and carry out drill designs. Stoping boundaries are finalised after detailed grade contouring of each stope and guidance from internal experts in the field to maximise ore extraction (in situ metal) within the stope grade. Regular grade predictions are done for each ring blasting and monthly feedback from beneficiation and tail-grade results is taken to reconcile the stope grade. Any visible discrepancy in stope grade is analysed using feedback from CMS survey. Any overbreak (external waste addition) or underbreak (loss of ore) compared to planned stope boundary is analysed volumetrically to understand the grade variation and suitable remedial measures in ring design and blasting control in subsequent stopes is undertaken.

It has been observed that prior to introduction of the CMS survey practice, stope dilution reasons or quantities could not be properly judged and, hence, lacked effective remedial measures to reduce it. However, it was felt that dilution from stope walls was mainly due to the improper setup of the production drill and borehole deviation in long blastholes, coupled by improper blast sequence and vibration. Figure 5 shows excessive HW dilution due to improper drilling in $\mathrm{BH}-10$, prior to CMS survey practice.

Steps have been taken at the design stage to plan the slot raise away from HW contact in each stope, leaving a temporary thin ore skin against shallow dipping weak HW rock types. This seeks to avoid any undercutting in the HW side. Moreover, engineered waste-patches within orebody (stoping boundary) are left unblasted to minimise dilution. Care is taken to light charge the blastholes against the weak stope walls ( $\mathrm{HW}$ and $\mathrm{FW}$ ) and also use delay sequencing from ring centre to the periphery to minimise chances of external dilution. 

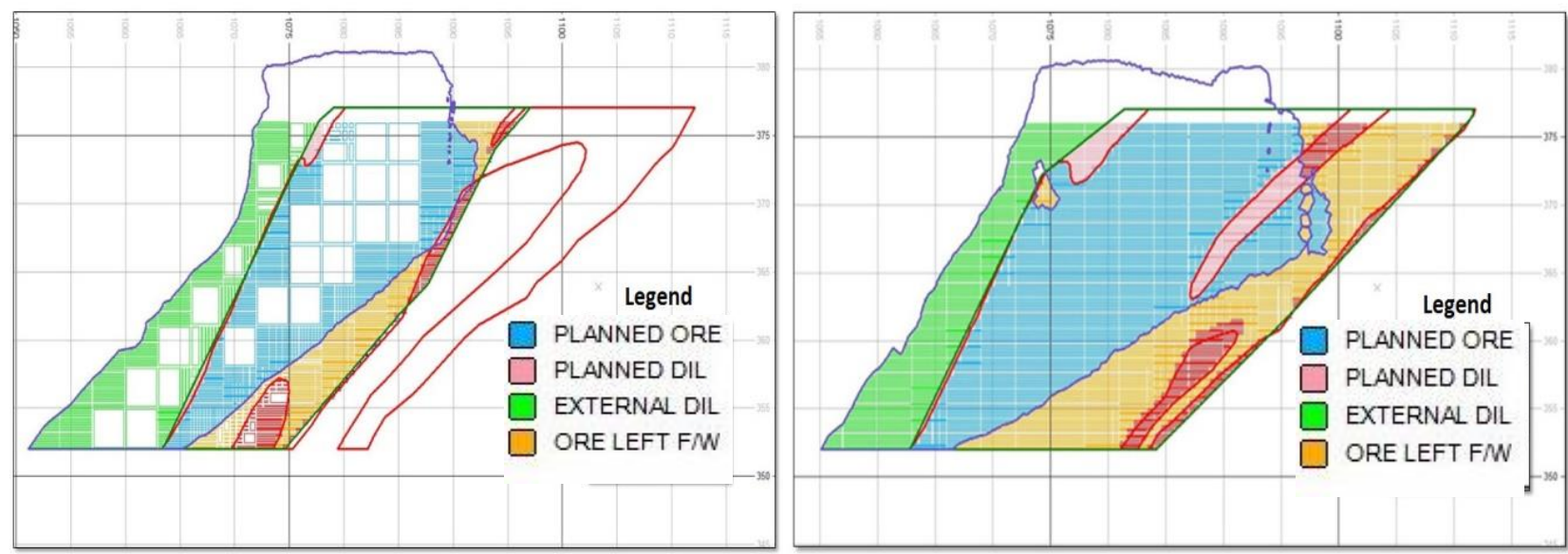

\begin{tabular}{|l|c|c|c|c|}
\hline Category & Tonnes & Pb\% & Zn\% & Ag g/t \\
\hline Planned Ore & 20430 & 0.71 & 3.07 & 34 \\
\hline Planned Dilution & 1640 & & & \\
\%Planned Dilution & $7.43 \%$ & & & \\
\cline { 1 - 2 } Mineable Ore & 22070 & 0.66 & 2.84 & 31 \\
\hline Overbreakage & 9930 & & & \\
\hline$\% O v e r b r e a k a g e$ & $31.0 \%$ & & & \\
\cline { 1 - 2 } & & & &
\end{tabular}

Figure 5 Summary statistics from the stope survey - $\mathrm{BH} 10$ in north and south sections

In secondary stopes, blastholes are designed leaving thin ore skin against the backfill (Figure 6) to avoid damage of backfill due to hole deviation or over drilling and blast vibrations to minimise fill dilution. The thickness of skin varies from 1-2.5 m, depending on orebody width. It gradually fails in the final stage of stope blasting and is recovered.

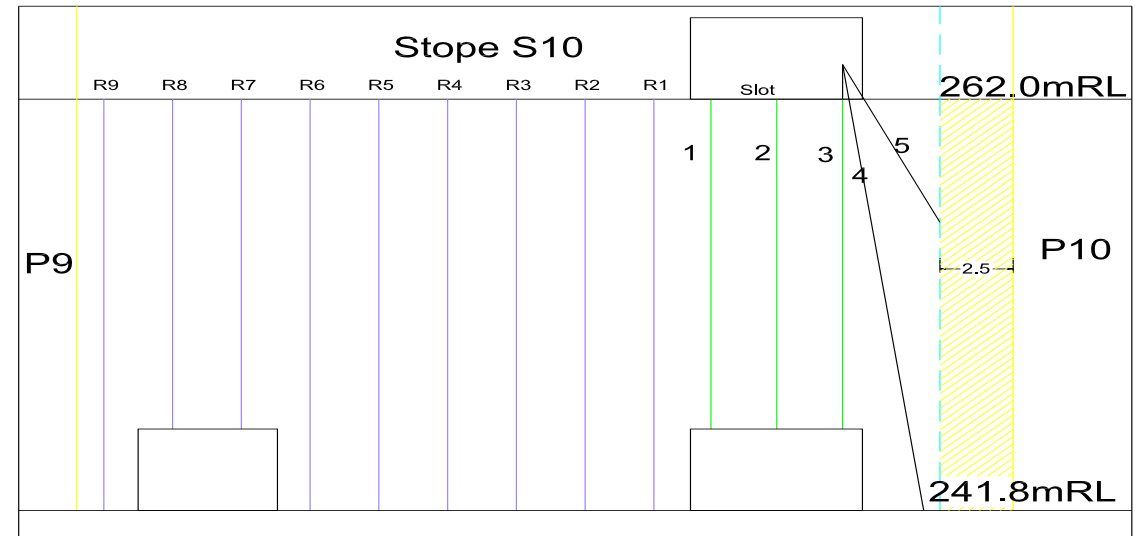

Figure 6 Ring design against the backfilled stope (Stope S10)

\section{$8 \quad$ Drilling and blasting}

Stopes are drilled with EHS (Solo Sandvik) drill machines using $64 \mathrm{~mm}$ holes for upholes in the trough and $102 / 89 \mathrm{~mm}$ holes for downholes in production rings. For longer holes $(>35 \mathrm{~m})$, ITH drills are used to drill $115 \mathrm{~mm}$ diameter holes. Although stope drilling has been outsourced, stringent measures have been observed by delegating sole ownership to dedicated engineers, imparting simulator and onsite training to operators, providing survey alignment lines on site and making contract supervisors responsible for the machine settings. Bore track instruments are used to monitor drill deviation. In stope blasts, emulsion explosive $(83 / 125 \mathrm{~mm})$ cartridges using a booster charge of 100/250/500 g with non-electric detonators at a drill factor of $12 \mathrm{t} / \mathrm{m}$ are in practice, achieving a 0.3-0.4 kg/t powder factor. Holes are always measured to 
identify over-drilling and to ensure that proper plugging is practiced. In order to reduce ground vibrations in large stope blasts, electronic detonators (IKON) are used under close guidance.

\section{$9 \quad$ Ground support and instrumentation}

The geotechnical conditions at SKM vary widely with frequent local geological disturbances. There are two prominent joint sets with a third one as random, mostly forming wedges in the roof and sides, and having calcite infillings rendering joints weak. Two of the joints are steeply dipping $\left(65^{\circ}\right.$ due west and at $80^{\circ}$ due north) and a third at a shallow dip of $20-25^{\circ}$, with mild to heavy folding, creating a fractured strata at frequent intervals (RMR is between 35 and 55). The HW rocks being mica-schist-chert formation is weak in shear and tensile loadings. The host rock is calc-silicate bearing dolomite and is comparatively stronger (RMR varies between 40 and 70).

All mine development headings are systematically supported by resin grouted rockbolts (at $1.5 \times 1.5 \mathrm{~m}$ spacing with $2.4 \mathrm{~m}$ long ribbed bolts). Additional cable bolting (with $6 \mathrm{~m}$ long cables in ring pattern) and wire meshing (welded wire mesh, $75 \mathrm{~mm}^{2}$ ) is done in areas where RMR is $<50$. Steel sets (using $300 \mathrm{~mm}$ long sections) are installed whereever poor and very poor ground is encountered. The freshly exposed development headings are regularly mapped by a dedicated geotechnical team and ground support recommendations are updated as and when required. The surface cap rock at $425 \mathrm{mRL}$ and crown pillars in each stoping panel are cable bolted with $10 \mathrm{~m}$ long cables (in ring pattern) to ensure better and long-term immediate ground stability and surface stability. In stopes where the orebody is shallow dipping and/or, the $\mathrm{HW}$ rock type is weak, the HW rocks are cable bolted (covering at least $3 \mathrm{~m}$ thick HW zone) with long cable bolts from HW drives or oredrives, to improve stability, reduce dilution and maintain operation safety (Figure 7).

\section{Stope HW pinning to reduce stope dilution}

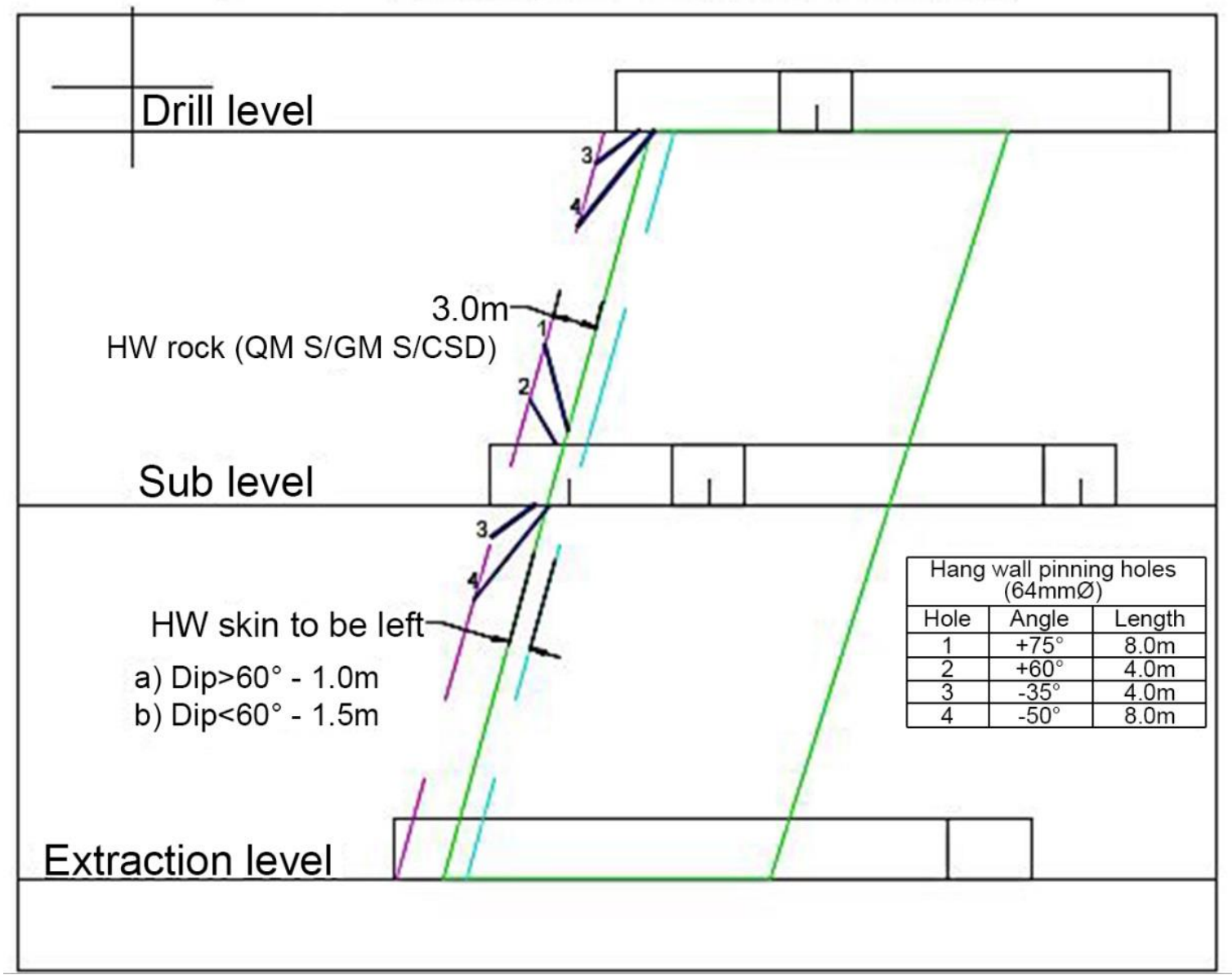

Figure $7 \mathrm{HW}$ cable bolting - stope HW pinning to reduce stope dilution 
Ground monitoring is done by using grouted multi-point borehole extensometers (MPBE) and vibrating wire uniaxial stress metres (VWSM), which are continually recorded and analysed by in-house rock mechanics engineers. Multipoint borehole extensometers are installed in the stope HW and uniaxial stress cells are installed in crown and rib pillars to monitor stress changes. Figure 8 shows the instrumentation. The feedback from these instruments is used for numerical modelling calibration purposes. Safety limits for ground deformation have been determined and are included in standard operating procedure to predict the chances of collapse and dilution.

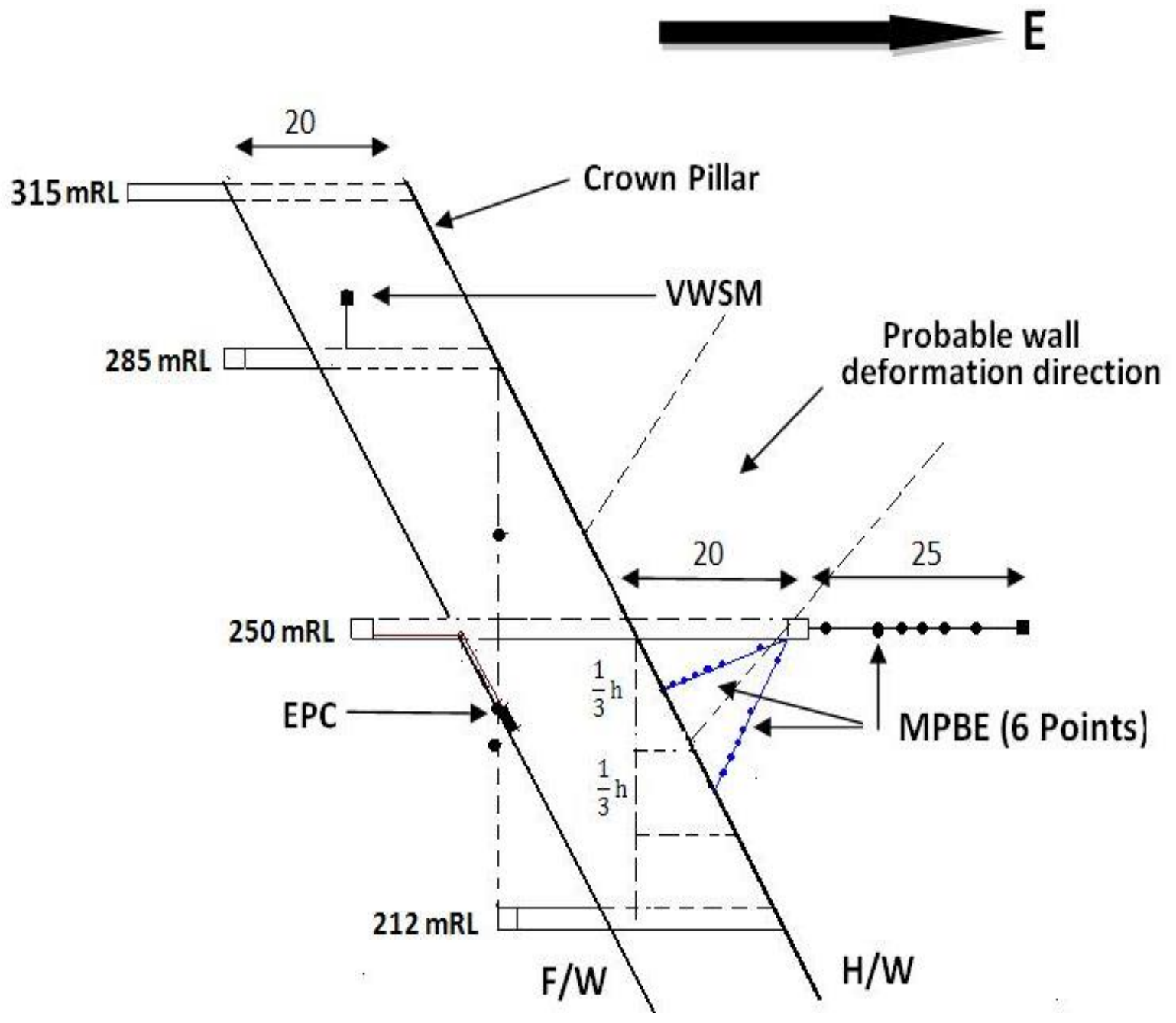

Figure 8 Ground instrumentation plan

\section{$10 \quad$ Mine filling}

The mine has a hydraulic backfill plant using classified tailings with a capacity of $80 \mathrm{~m}^{3}$ per hour at a pulp density of 1.73. Lately, a paste filling plant has also been commissioned and has a fill capacity to meet $2 \mathrm{Mt} /$ year production that can be enhanced to meet $3 \mathrm{Mt} /$ year production. Paste fill is poured with a solids content of about $78-79 \%$, at pour rates of $140-240 \mathrm{~m}^{3} /$ hour and a cement binder ratio of $>6 \%$. Figure 9 shows how the binder ratio for various stope spans has drastically improved the stoping cycle time and fill stability during secondary stoping and aided better regional stability. Figure 10 shows the free standing exposed fillwall. The primary stage stope fillwall stood $76 \mathrm{~m}$ vertically with stope width of $20 \mathrm{~m}$ for six months after secondary panel extraction, after which the secondary panel void was filled. The fill dilution in secondary stoping is reduced from $6 \%$ in case of cemented hydraulic filling, to less than $2 \%$ in case of paste filling. 


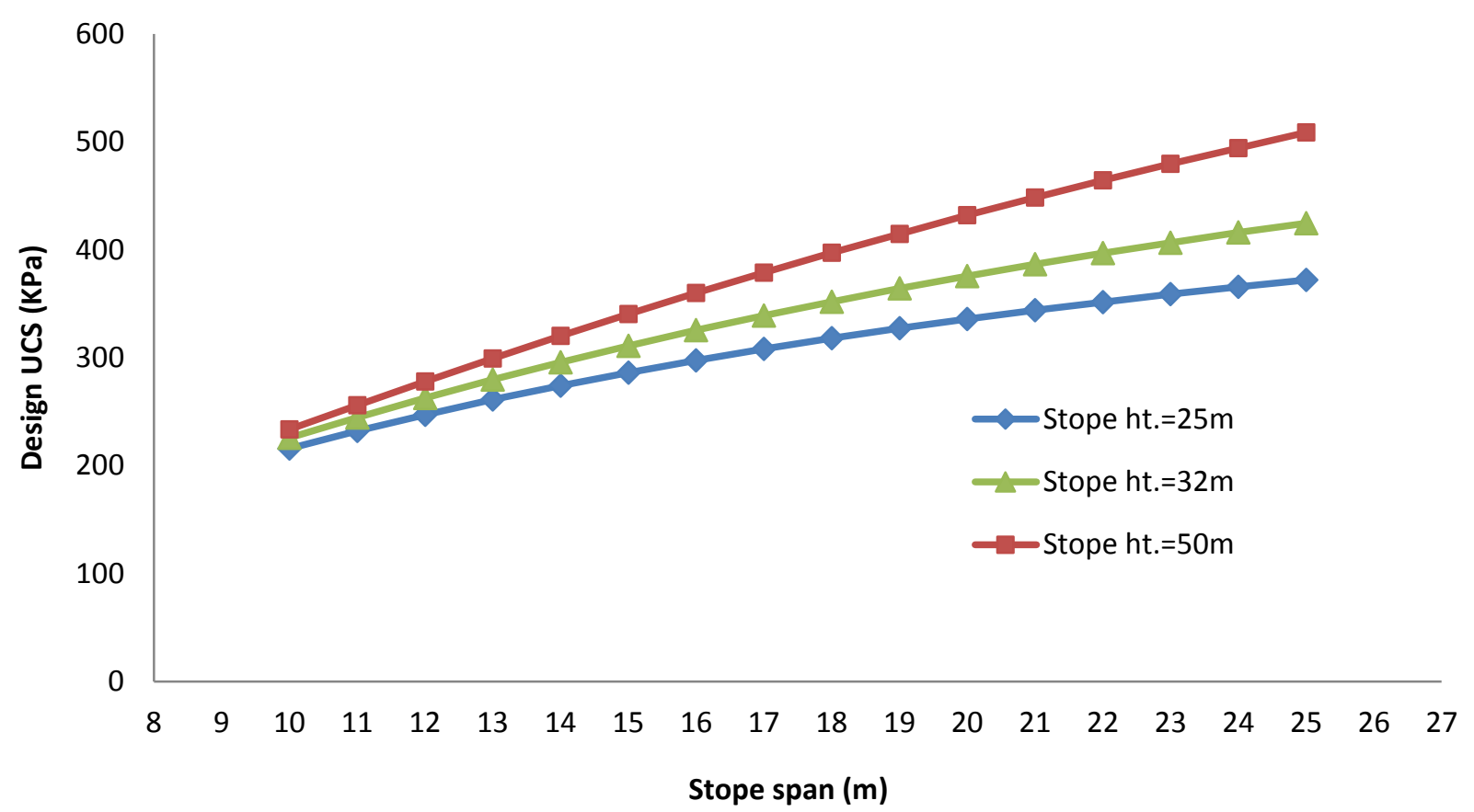

Figure 9 Required fill strength for stope span

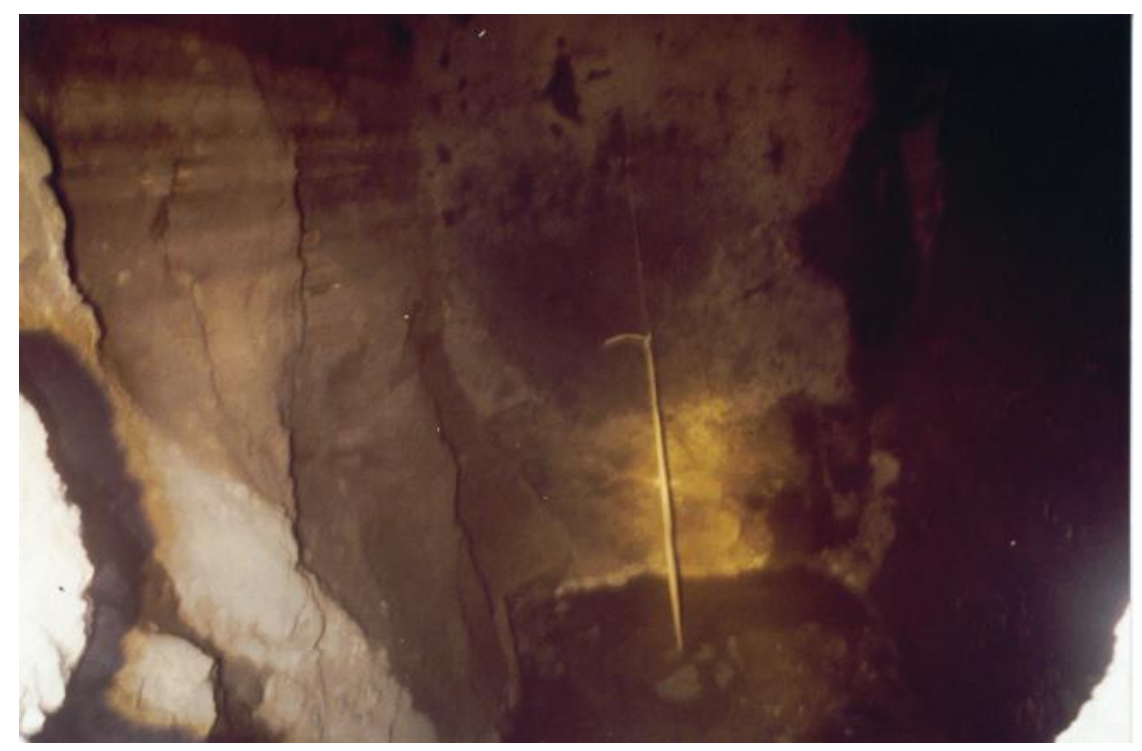

Figure 10 Stable fillbody exposed in secondary stoping

\section{Vibration control}

The mine is located near a village which is fairly populated with poor construction dwellings. Hence the mine blasts are strictly kept under control so that ground vibrations at surface are kept below safe limits ( $15 \mathrm{~mm} / \mathrm{s}$, for frequency $>40 \mathrm{~Hz}$, as recommended by Directorate General of Mine Safety, Government of India). The shortest distance of stope blasts from the village boundary vary from $125-250 \mathrm{~m}$. Continual monitoring was done in-house, and also by a scientific team (CIMFR, Dhanbad, Government of India). Based on the safe vibration limit as described above, it is recommended that the maximum charge per delay (MCPD) be kept below $80 \mathrm{~kg} /$ delay and total charge is also to be limited to $800 \mathrm{~kg} / \mathrm{blast}$. This is achieved through multiple blasts (3-4 m lifts) of each ring. However, the total charge increase and optimisation of delay intervals using electronic detonators are also carried out under the guidance of the experts when large blasts are necessary. This in turn has kept stope wall dilution caused by vibration under control. 


\section{Cavity monitoring survey}

As a practice, all stope voids after completion of mucking are surveyed with CMS. The camera of the system is extended from suitable levels in the stope void, and continuous laser survey is done at high resolution.

CMS at SKM is being used to survey the final geometry of open stopes to determine the amount of over/underbreak in order to assess the magnitude of dilution and poor ore extraction problems and compare the design versus actual stope profile. It works in conjunction with Datamine ${ }^{\circledR}$ mine planning software as an integration platform to combine geology, mine planning and survey information in a 3D graphic environment. CMS are conducted by the geology department, and the results are imported into Datamine ${ }^{\circledast}$ Studio where stope excavation solids are created. The solids are accessed and displayed in 2D sections, together with the orebody contacts, to determine the stope overbreak and underbreak.

Initially, CMS surveys showed that major overbreak was occurring mainly in the HW of open stopes (Figure 11).
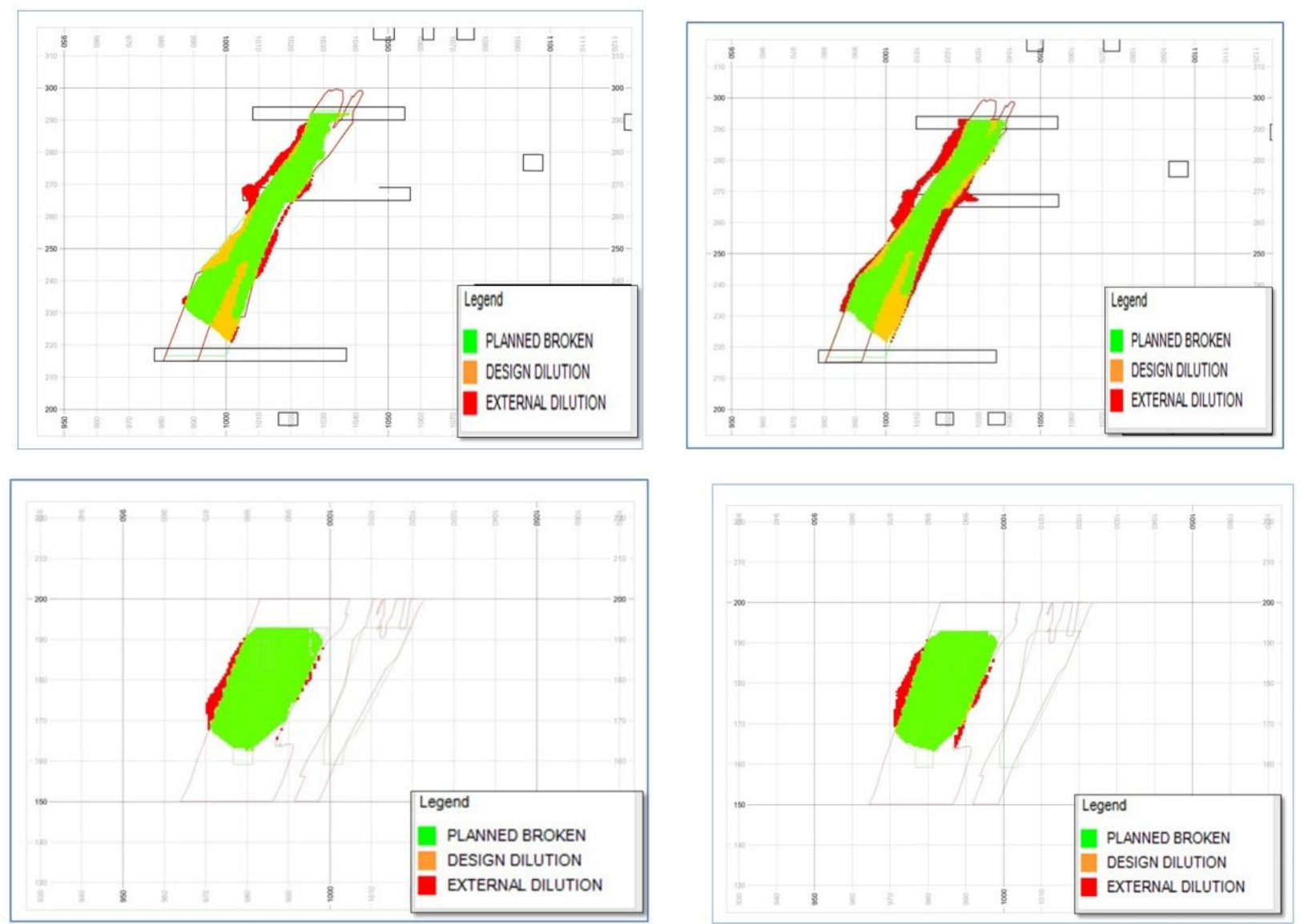

Figure 11 CMS of stope P-03 and AP-09 showing HW dilution

Corrective actions, as discussed in the mine planning section, were put in place by the mine dilution committee. This resulted in a much better performance of stopes. The results show reduced external dilution within reasonable limits (external dilution reduced from $8.83 \%$ in 2011-2012 to 3.28\% in 2014-2015). The introduction of the system has increased the awareness and ownership of the operators and improved the quality of drilling and blasting. CMS pictures (Figure 12) show marked improvements in HW overbreak and external dilution in stopes BH-11 and P-12. 


\section{CMS of Stope-BH11}
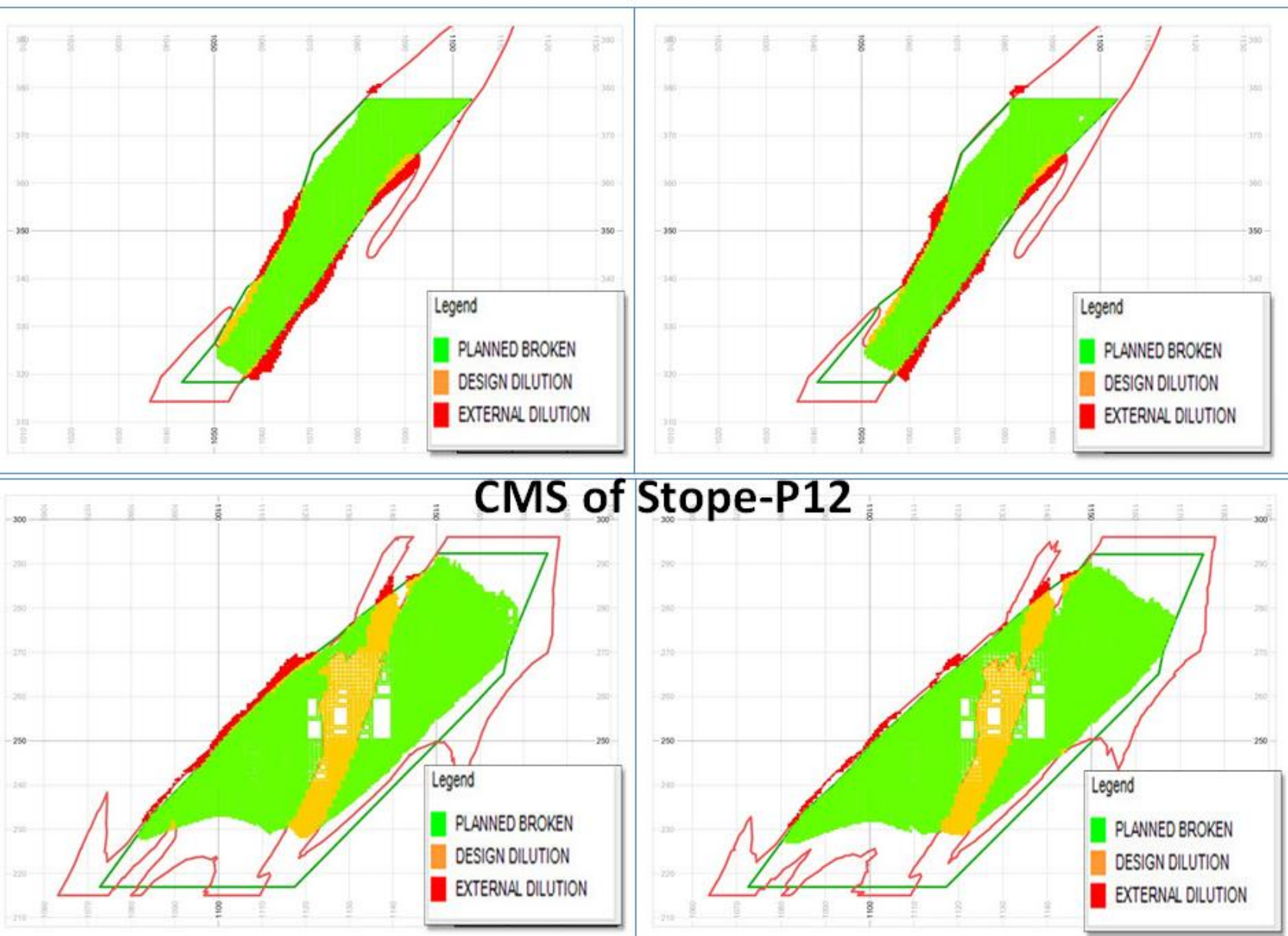

Figure 12 CMS results of $\mathrm{BH}-11$ and $\mathrm{P}-12$ showing reduced external dilution

\section{Grade contouring to reduce planned dilution}

While the HW/FW overbreak was largely confirmed and controlled through the above processes, planned dilution could be minimised through the use of grade contours and identifying low-grade ore patches left as waste pillars in between the stopes. Combining high-grade with adjacent low-grade zones in a stable stope geometry has been possible, giving higher metal extraction with economic stope grade. HW cable bolting also helped in suitably isolating and segregating waste from blasted ore. Figure 13 shows sections of stope grade contouring and a selection of the optimum stoping boundary. The planned dilution of stope S-10 could be improved from 16-13.2\% (actual grade) through detailed stope grade contouring. External dilution is constant at $8 \%$ only. 


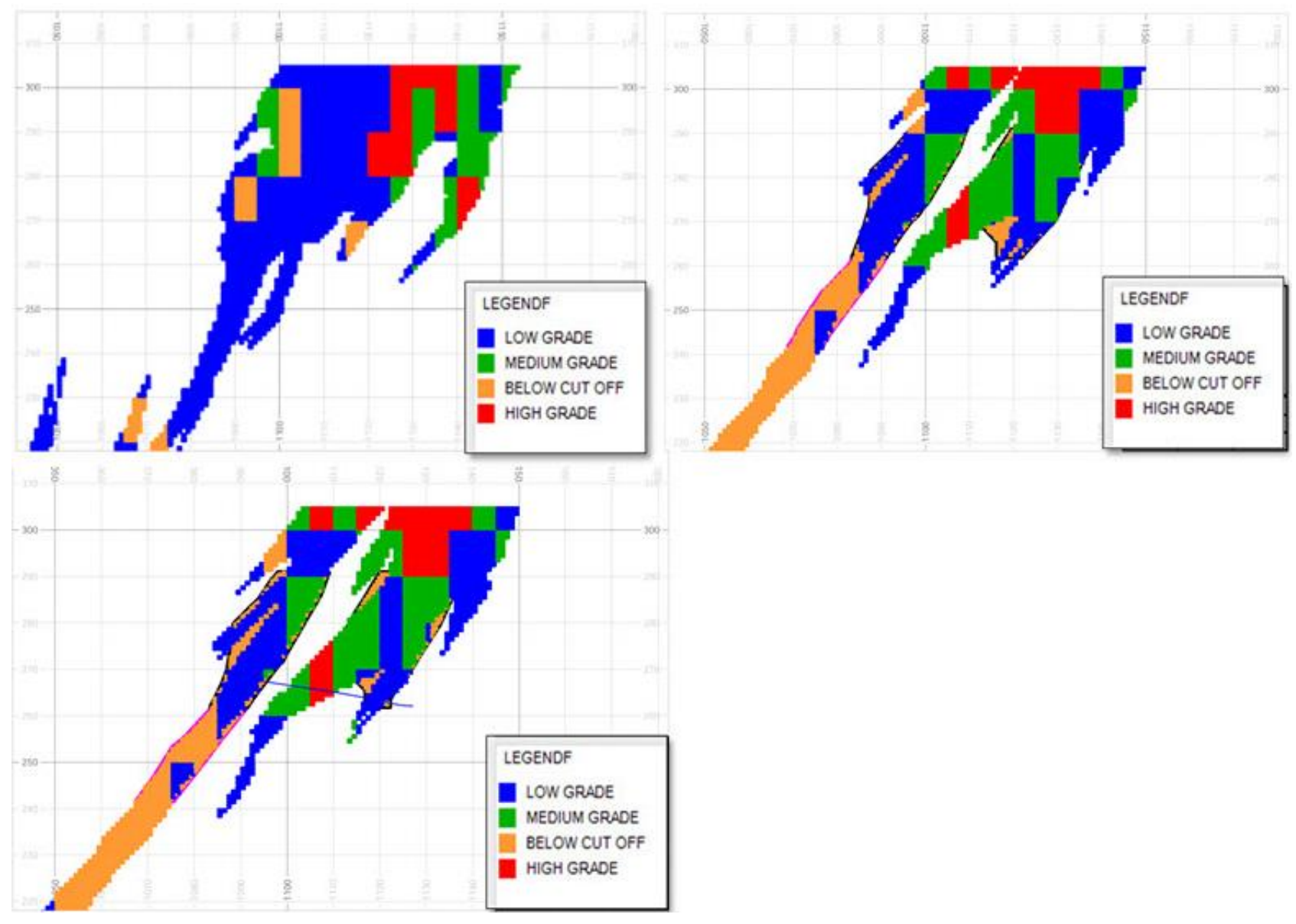

(a)

\begin{tabular}{|c|c|c|c|c|c|c|c|c|c|c|c|c|c|c|c|c|}
\hline & & \multicolumn{5}{|c|}{ In-Situ } & & & & \multicolumn{7}{|c|}{ Mineable } \\
\hline Stope & LEVEL/AREA & TONNES $\mathrm{P}$ & & $n$ & TMC & $\mathrm{Ag}$ & P Dil (T) & $\%$ Pdil & ext_Dil & Tons & $\mathrm{Pb}$ & $\mathrm{Zn}$ & & TMC & $\mathrm{Ag}$ & \\
\hline \multirow{3}{*}{ Case-1 } & $290-265 \mathrm{HW}$ & 32493 & 1.12 & 2.81 & 3.93 & 68 & 2794 & $7.4 \%$ & $8 \%$ & 33339 & & .74 & 2.38 & 3.1 & & 58 \\
\hline & $265-240$ & 12416 & 1.09 & 2.70 & 3.79 & 60 & 3246 & $19.5 \%$ & $8 \%$ & 14657 & & .72 & 2.28 & 3.0 & & 51 \\
\hline & 290-265FW & 46193 & 2.23 & 3.32 & 3.78 & 140 & 10174 & $16.9 \%$ & $8 \%$ & 52855 & & 65 & 2.81 & 4.4 & & 118 \\
\hline Total & & 91102 & 1.68 & 3.06 & 3.84 & 103 & 16214 & $14 \%$ & $8 \%$ & 100851 & & .21 & 2.59 & 3.8 & 30 & 89 \\
\hline
\end{tabular}

(b)

\begin{tabular}{|c|c|c|c|c|c|c|c|c|c|c|c|c|c|c|c|c|}
\hline & & \multicolumn{5}{|c|}{ In-Situ } & & & & \multicolumn{7}{|c|}{ Mineable } \\
\hline \multirow{4}{*}{ Case-2 } & LEVEL/AREA & TONNES $\mathrm{P}$ & $\mathrm{Pb}$ & \begin{tabular}{l|l}
$\mathrm{Zn}$ & $\mathrm{T}$ \\
\end{tabular} & TMC & $\mathrm{Ag}$ & P Dil (T) & $\%$ Pdil & ext_Dil & Tons & $\mathrm{Pb}$ & $\mathrm{Zn}$ & & TMC & $\mathrm{Ag}$ & \\
\hline & 290-265HW & 32493 & 1.12 & 2.81 & 3.93 & 68 & 2794 & $7.4 \%$ & $8 \%$ & 33339 & 0.7 & & 2.38 & 3.12 & & 58 \\
\hline & 290-265FW & 46193 & 2.23 & 3.32 & 5.56 & 140 & 10174 & $16.9 \%$ & $8 \%$ & 52855 & 1.6 & 55 & 2.81 & 4.46 & 46 & 118 \\
\hline & Total & 78685 & 1.77 & 3.11 & 4.88 & 110 & 12968 & $13.2 \%$ & $8 \%$ & 86194 & 1.2 & 29 & 2.65 & 3.9 & & 95 \\
\hline BP & 290-215mRL & 35831 & 2.08 & 4.62 & 6.71 & 115 & 6864 & $16 \%$ & $8 \%$ & 37571 & 1.6 & 51 & 3.57 & 5.18 & 18 & 89 \\
\hline
\end{tabular}

(c)

Figure 13 (a) grade contouring of S-10 stope and reduction of planned dilution: (b) Case 1 - initially planned between 290-240 mRL in HW and FW lens; (c) Case 2 - mining boundary revised based on grade contours and excluded $265-240 \mathrm{mRL}$ to reduce total dilution and grade improvement 


\section{Various measures taken to minimise dilution}

Following are the various measures being taken to keep stope dilution under control and reduce direct and indirect mining cost:

- Each stope is planned on an individual basis after extensive in-house discussions.

- Introduction of grade contours for each stope lead to better mining boundaries, ring design and production planning, and daily grade forecasts.

- Implementation of CMS to check external dilution in open stopes and setting up of a stope history database. The results from the CMS showed that stopes with overbreak of $5 \mathrm{~m}$ or less could be controlled effectively by HW cable bolting, specifically where incompetent ground conditions and variable HW contacts are present.

- To reduce the effect of HW dilution in the weak schist zone, the stope rings are designed leaving a zone of $1.7 \mathrm{~m}$ thick against HW contact undrilled. This ensures minimum blast damage in HW.

- For shallow dipping HW geometry, i.e. less than $50^{\circ}$, a drill hole ore stand-off of 2-3 m (top to bottom) against the HW is left either undrilled, uncharged or, by using lower density explosives, left to collapse by gravity at a delayed stage at the end of stoping.

- Unnecessary undercutting of the HW at extraction and at sublevels during the development stage is avoided. If any crosscut has been driven into the HW, unknowingly, the HW rocks are cable bolted from within the orebody in the region, in ring pattern to stabilise the overhang/undercut wall rocks.

- Blasthole drill deviations are minimised by proper set-up of the drill and appropriate drill practices (feed pressure, rotation and control). All drill holes exceeding the designed length are plugged before blasting.

- All stoping geometry and pillars are designed based on numerical modelling and feedback from ground instrumentation.

- Mining production personnel, such as shift bosses and loader operators are aware of dilution.

- Strict supervision of stope development and drill setting, both in primary and secondary stopes.

- Tracking of development waste generated and its destination.

\section{Achievements in dilution control}

The above system improvements, technology application, operational practices, positive interaction between departments and good team spirit have led the mine to achieve substantial reduction in overall mine dilution. Figures 14 and 15 show that, in general, there has been consistent improvement in dilution control in the mine since 2011-2012 through 2014-2015, reducing planned dilution (planned dilution (PDil)) from 17.23-5.72\%, and external dilution (external dilution (EDil)) from 8.83-3.28\%. 


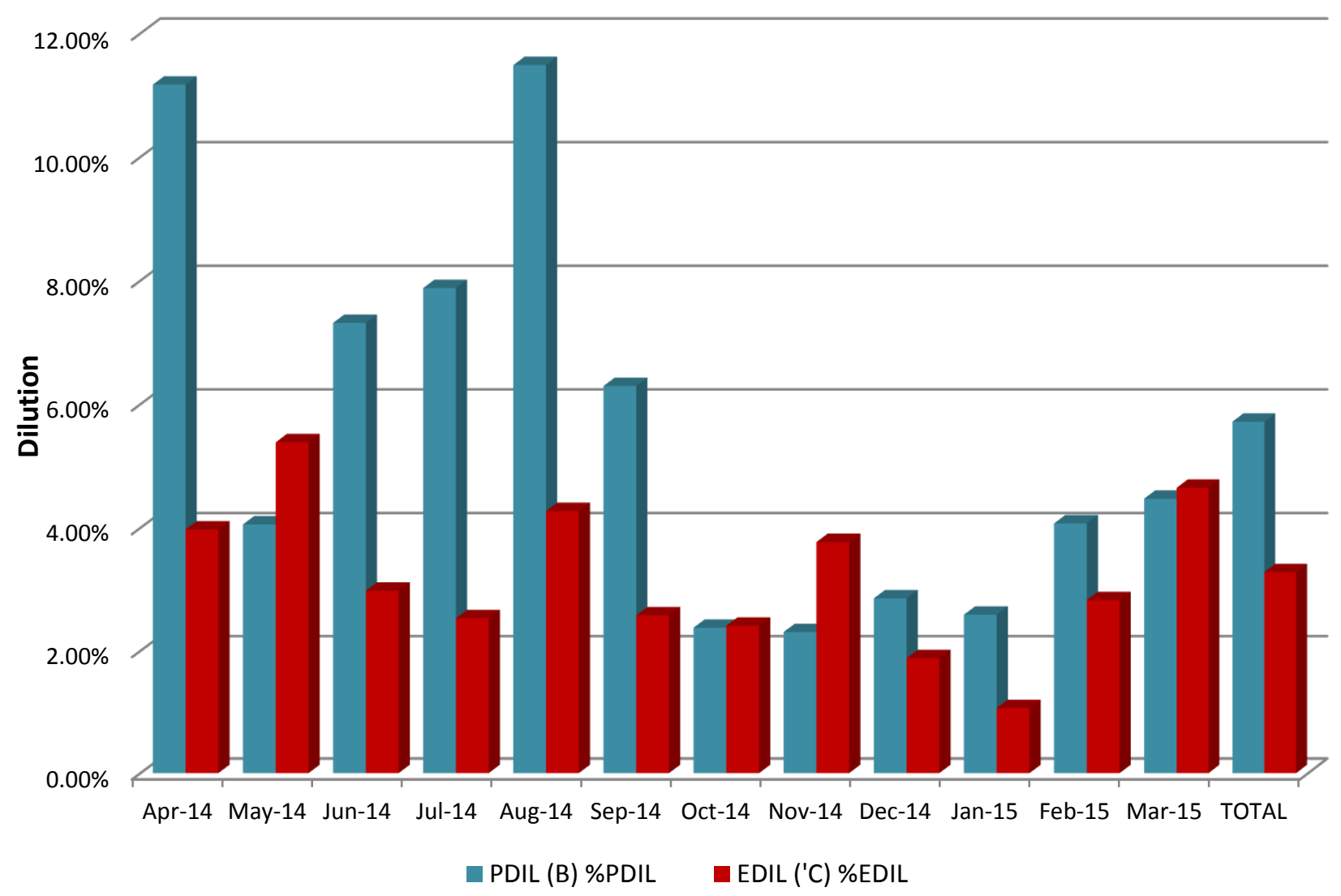

Figure 14 Dilution trend YTD 14-15

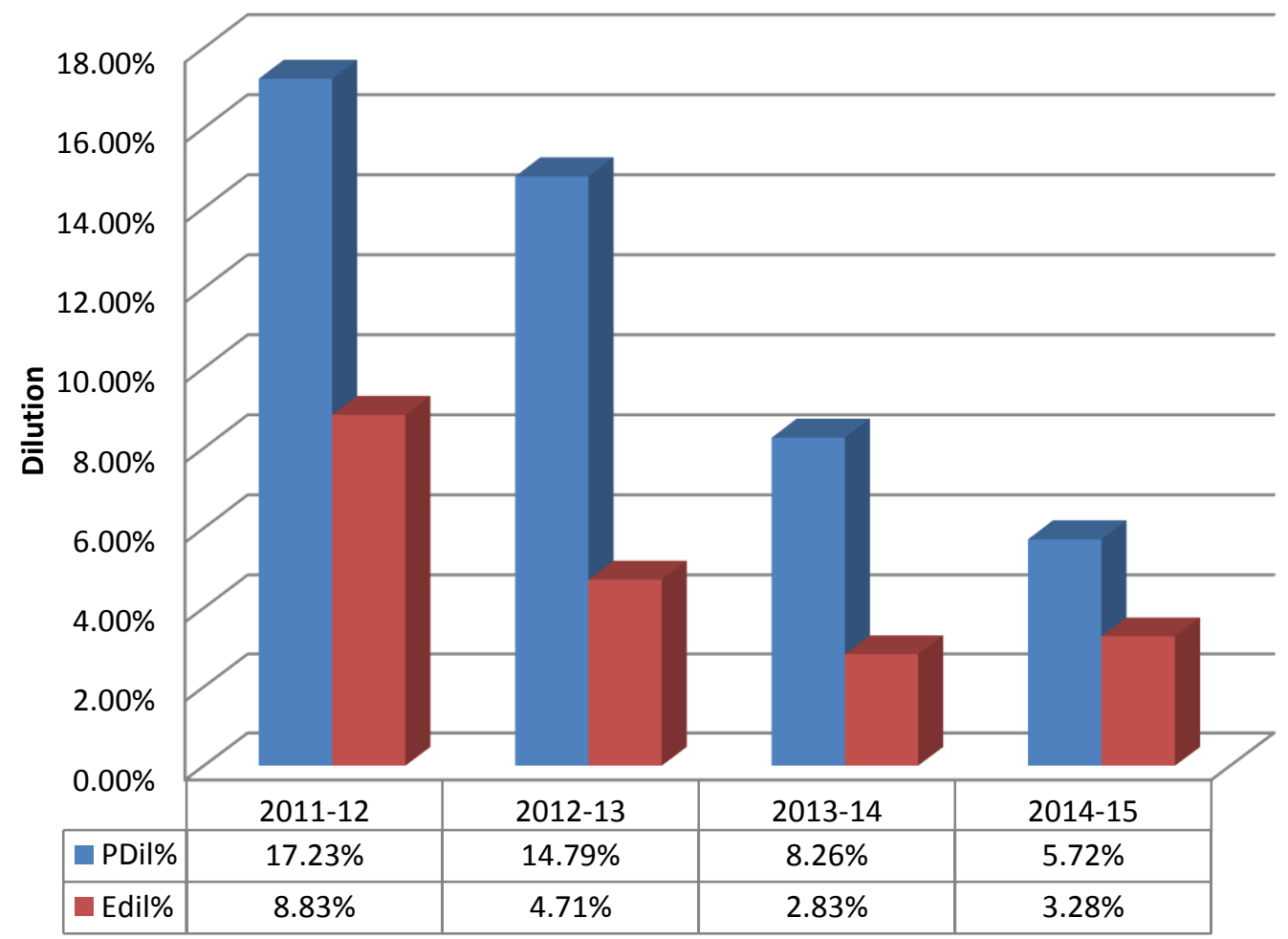

Figure 15 Cumulative dilution comparison 


\section{Conclusion}

Dilution at SKM was steadily controlled and effectively reduced through an integrated interdisciplinary approach. The major initiatives included:

- Underground exploration drilling enabling proper orebody delineation and detailed grade contouring, using versatile mobile coring rigs (MCR-U6).

- Comprehensive understanding of the geotechnical conditions of each stoping panel.

- Stable and optimum stope boundary definition.

- Stringent design of drilling patterns and blast sequencing.

- Effective use of the CMS tool for quantifying dilution over- and underbreak in fine tuning of stope design.

- Strict supervision in drilling and use of controlled blasting of HW and FW holes.

- Continual tracking of underground waste and its handling.

- Imparting high level of dilution awareness among shift bosses, engineers and operators.

The methodology has effectively involved an integrated approach, namely excavation design from orebody delineation to stope extraction where the interaction among geology, mine planning, rock mechanics and operating personnel has been essential throughout the entire mining process.

\section{Acknowledgement}

The authors gratefully acknowledge the support and encouragement given by Hindustan Zinc Ltd management to prepare and allow the publishing of this paper. The help and technical support given by Mr V Chittora and Mr L Chordia, mine planning and geology, and Mr D Tailor, planning engineer, in data collection, tabulation and drafting to final format is also acknowledged. 